\title{
Changes of Leaf Anatomical Profile of Cocoa Clones Seedlings in Response to Drought
}

\author{
Fakhrusy Zakariyya $^{\left.1^{*}\right)}$, Didik Indradewa ${ }^{2}$, and Teguh Iman Santoso ${ }^{1)}$ \\ ${ }^{1)}$ Indonesian Coffee and Cocoa Research Institute, J1. PB. Sudirman 90, Jember, Indonesia \\ ${ }^{2}$ Faculty of Agriculture, Gadjah Mada University, Jl. Flora, Bulaksumur, Yogyakarta, Indonesia \\ ${ }^{*}$ Corresponding author: fakhrusy.zakariyya@gmail.com \\ Received: 17 July 2019 / Accepted: 18 September 2019
}

\begin{abstract}
Cocoa is a plant that is very sensitive to drought during its growth and development phase, which causes changes up to the anatomical and morphological level. This research is aimed to examine the changes on several leaf anatomical characteristics of three cocoa clones under the drought stress. This research was conducted in a greenhouse of Indonesian Coffee and Cocoa Research Institute, Jember, East Java, Indonesia in January - December 2017. The research was designed using randomized complete block design with two factors including clones and watering time interval, with three replications. The clone factor comprised of ICS 60, KW 641, and Sulawesi 1. The result showed that the clones of Sulawesi 1 and KW 641 cocoa had a higher mesophyll thickness, lower stomatal density, narrower stomatal opening, thicker abaxial and adaxial epidermis, and higher relative water content compared to ICS 60 clone. The 8-day watering interval caused a decrease in mesophyll thickness, leaf thickness, increase in stomatal density, stomatal closure, decrease in abaxial epidermis thickness, and decrease in water status within the plant tissue. The thicker the leaf mesophyll tissue, the higher the leaf water content was. This showed that the water status within a plant leaf tissue determined by the leaf mesophyll thickness.
\end{abstract}

Keywords: Cocoa, clone, drought, leaf, anatomy

\section{INTRODUCTION}

Cocoa is a plant that is very sensitive to drought during its growth and development phase. This is because cocoa requires adequate water to live. Drought is one of the environmental threats that significantly influence cocoa growth and development, as well as its productivity compared to other environmental threats. A threat from drought will occur if the amount of water available is inadequate to the plant need, along with the transpiration process that continually happens (Mathobo et al., 2016). Threats to the plant will cause a disorder in the cellular functions and negatively impact the plant growth and production (North et al., 2019).

To survive, plants generally involve multiple cellular changes as an adaptation mechanism in response to its environment, for instances, the control of stomatal opening and closure and the thickening of epidermis cells to decrease the transpiration mechanism. Studies on cellular changes in response to drought stress threat of cocoa plant have not been explored much. Zanneti et al. (2016) showed that the cocoa plant characteristics changes due to drought threat include a change in the stomatal density. Mardiyah 
(2014) explained that the anatomical changes on rice plant due to drought stress include a decrease in epidermis thickness, endodermis thickness, diameter of vascular bundle cell, mesophyll thickness, yet, an increase in the amount of trichome. The leaf mesophyll is a leaf tissue which anatomically located in between the adaxial and abaxial epidermis. This tissue comprises of palisade parenchyma, spongy parenchyma, and vascular bundle tissues. The functions of these tissues include as a water storage, air exchange, and a place for photosynthesis process due to the presence of chlorophyll pigments. Research by Haffani et al. (2017) reported that plants that are threatened by drought can cause a thickening of mesophyll cells and increase in stomatal density.

The anatomical characteristic changes can be used as an ideotype to identify types of dry resistant plants. Based on several previous studies, the leaf anatomical characteristics became the focus to resistant characteristic identification including the characters of the stomata (Agurla et al., 2018), mesophyll, and epidermis characteristics (Binks et al., 2016). The stomatal density typically becomes a criterion to identify and choose the genotype which is relatively tolerant toward drought (Khosroshahi et al., 2014). The stomatal density is a characteristic that can influence gas exchange. Stomata have a role in the transpiration process between leaves and atmosphere, meanwhile, mesophyll on leaves acts as spare water storage in the leaves during drought. These changes at the cellular level have the potential to influence the cocoa plant vigor. Prawoto (1991) stated that stomata and palisade cells in cocoa leaves influence the plant vigor. The good influence on plant vigor can be affected by the water status within the plant body, which is maintained well. This research is aimed to examine the changes on several leaf anatomical characteristics of some clones under the drought stress.

\section{MATERIALS AND METHODS}

This research was conducted at the greenhouse of Indonesian Coffee and Cocoa Research Institute, Jember, East Java, Indonesia. This research was conducted from January-December 2017. The microclimate that was observed during the research included temperature, humidity, and light intensity. The average daily temperature during the research was $26.5-28.5^{\circ} \mathrm{C}$, with the highest temperature of $32.7^{\circ} \mathrm{C}$ and the lowest of $22.5^{\circ} \mathrm{C}$. The relative daily humidity was $84.67 \%$. The light intensity throughout the period of research was $985.5{\mathrm{~J} . \mathrm{cm}^{2} \text {.day }}^{-1}$.

This research used seedlings from top grafting with different scion clones and then grafted to the Scavina 6 clone seedlings. The rootstock derived from the legitimate seedlings from a 6-month-old Scavina 6 clone was grafted with three cocoa clones, which were ICS 60, Sulawesi 1, and KW 641. The research was designed by a random model which was repeated three times. The first factor was the ICS 60 clone as succeptible clone to drought according to Winaryo et al. (1997), Sulawesi 1, and KW 641 as resistant clone to drought, according to Zakariyya et al. (2016). The second factor was the treatment of watering interval in which the watering of every 2 days (regular watering), 5 days (moderate stress), and 8 days (severe stress). The watering was conducted by adding $750 \mathrm{~mL}$ of water. Several variables observed in the fully grown leaves included the stomatal density, stomatal opening width, mesophyll thickness, adaxial and abaxial epidermis thickness, leaf thickness, and relative water content in the leaves. The stomata characteristics were observed by applying nail polish on the leaf abaxial. The result of the leaf stomata cell was then placed upon an object-glass and observed under a microscope. The stomata characteristic measurement includes the stomatal density and opening width. The 
observation toward stomata characteristic was conducted at the age of 80 days after treatment. The leaf thickness was measured by using a caliper on the leaves that have fully grown or young fully expanded leaf. The observation of leaf thickness was also conducted 80 days after treatment.

On the leaf anatomy observation, the sample leaves were fixated in $70 \%$ alcohol. The transversal section refer to semi-permanent preparation (Sass, 1951). The anatomical characteristic observation includes the epidermis and palisade thickness at the end of observation. The measurement of anatomical characteristics was conducted using the image raster software (Macinos, Indonesia). The documentation used an instrument of microscope photo (Optilab Advance-Macinos, Indonesia). The leaf cellular characteristic observation was conducted on 80 days after the treatment. The content of relative water was calculated based on the equation: $100 \mathrm{x}$ (Wf-Wd)/ (Ws-Wd), wherein Wf is the fresh weight, $\mathrm{Wd}$ is the leaf dry weight, and Ws is the leaf weight after thoroughly filled with water (cocoa leaves samples were cut with a diameter of $1 \mathrm{~cm}$ without the leave lamina and midrib for 12 hours).

The data resulted from the observation of multiple observation variables were then analyzed using the analysis of variance (ANOVA) with $\alpha=5 \%$. If the variance analysis result acquired is $\mathrm{F}$ hit $>\mathrm{F}$ table, that means there was an significant difference between treatments, then it was continued with the Tukey Test (Gomez \& Gomez, 1995).

\section{RESULT AND DISCUSSION}

Leaf is a plant organ that is sensitive to dry condition. The response of plant toward drought stress can be seen based on the leaf anatomical change. Table 1 showed information regarding leaf, mesophyll, and lower epidermis thickness under the influence of single factor of the clone and watering interval treatment, meanwhile, the upper epidermis was influenced by the single factor of clone. The watering interval of 5 days and 8 days significantly influenced the decrease in values of leaf thickness, mesophyll thickness, compared to the watering interval of 2 days. The mesophyll thickness is also significantly influenced by the watering interval treatment. The mesophyll of the seedlings watered every 5 days and 8 days significantly showed a thinner $10.85 \%$ and $19.58 \%$ compared to the ones watered every 2 days. The drought stress could cause mesophyll to become thinner. Furthermore, Table 1 also informed that the watering interval treatment only significantly influenced the abaxial epidermis. The increase of watering interval from 2 days to 8 days caused an abaxial epidermis thickening up to $11.11 \%$.

If seen from the clone treatment, KW 641 and Sulawesi 1 clones had thicker leaves, mesophyll tissue, adaxial and abaxial epidermal tissue compared to ICS 60 clone. This indicates that the genetic influence is very determining to the epidermal growth. Visually, the picture of the tissue is depicted in Figure 1. Santoso et al. (2017) state that the thickness of upper epidermal tissue is around 16.95$22.62 \mu \mathrm{m}$ while abaxial epidermis is thinner, which is $8.68-10.45 \mu \mathrm{m}$, in which both are influenced by the types of cocoa clones.

The leaf thickness is closely related to the tissues within the leaves, one of them is mesophyll. Figure 2 depicts the linear relationship between the leaf thickness and mesophyll tissue of the cocoa leaf. The thicker the mesophyll, the thicker the leaves will be. This indicates that by observing the leaf thickness non-destructively, it can acquire the overview of mesophyll thickness within the leaf tissue. 
Table 1. Leaf thickness, mesophyll tissue thickness, leaf adaxial and abaxial epidermal tissue thickness of some cocoa leaf clones on several levels of drought threats

\begin{tabular}{lcccc}
\hline $\begin{array}{l}\text { Watering interval } \\
\text { (days) }\end{array}$ & $\begin{array}{c}\text { Leaf } \\
\text { thickness, mm }\end{array}$ & $\begin{array}{c}\text { Mesophyll } \\
\text { thickness } \\
(\mu \mathrm{m})\end{array}$ & $\begin{array}{c}\text { Adaxial epidermal Abaxial epidermal } \\
\text { thickness } \\
(\mu \mathrm{m})\end{array}$ & $\begin{array}{c}\text { Abkness } \\
(\mu \mathrm{m})\end{array}$ \\
\hline 2 (normal) & $0.24 \mathrm{a}$ & $96.51 \mathrm{a}$ & $20.32 \mathrm{a}$ & $9.36 \mathrm{a}$ \\
5 (moderate stress) & $0.19 \mathrm{~b}$ & $86.04 \mathrm{~b}$ & $20.13 \mathrm{a}$ & $9.80 \mathrm{ab}$ \\
8 (severe stress) & $0.18 \mathrm{~b}$ & $77.61 \mathrm{c}$ & $21.46 \mathrm{a}$ & $10.53 \mathrm{~b}$ \\
\hline Clones & & & & $8.71 \mathrm{n}$ \\
\hline ICS 60 & $0.17 \mathrm{n}$ & $83.33 \mathrm{n}$ & $10.39 \mathrm{~m}$ \\
KW 641 & $0.22 \mathrm{~m}$ & $87.42 \mathrm{mn}$ & $20.81 \mathrm{~m}$ & $10.59 \mathrm{~m}$ \\
Sulawesi 1 & $0.22 \mathrm{~m}$ & $89.41 \mathrm{~m}$ & $21.80 \mathrm{~m}$ & \\
\hline
\end{tabular}

Notes: The numbers followed by the same letter on the collum and/or row shows the insignificant difference according to Tukey 5\%; The mark (-) indicates the absence of interaction among factors.

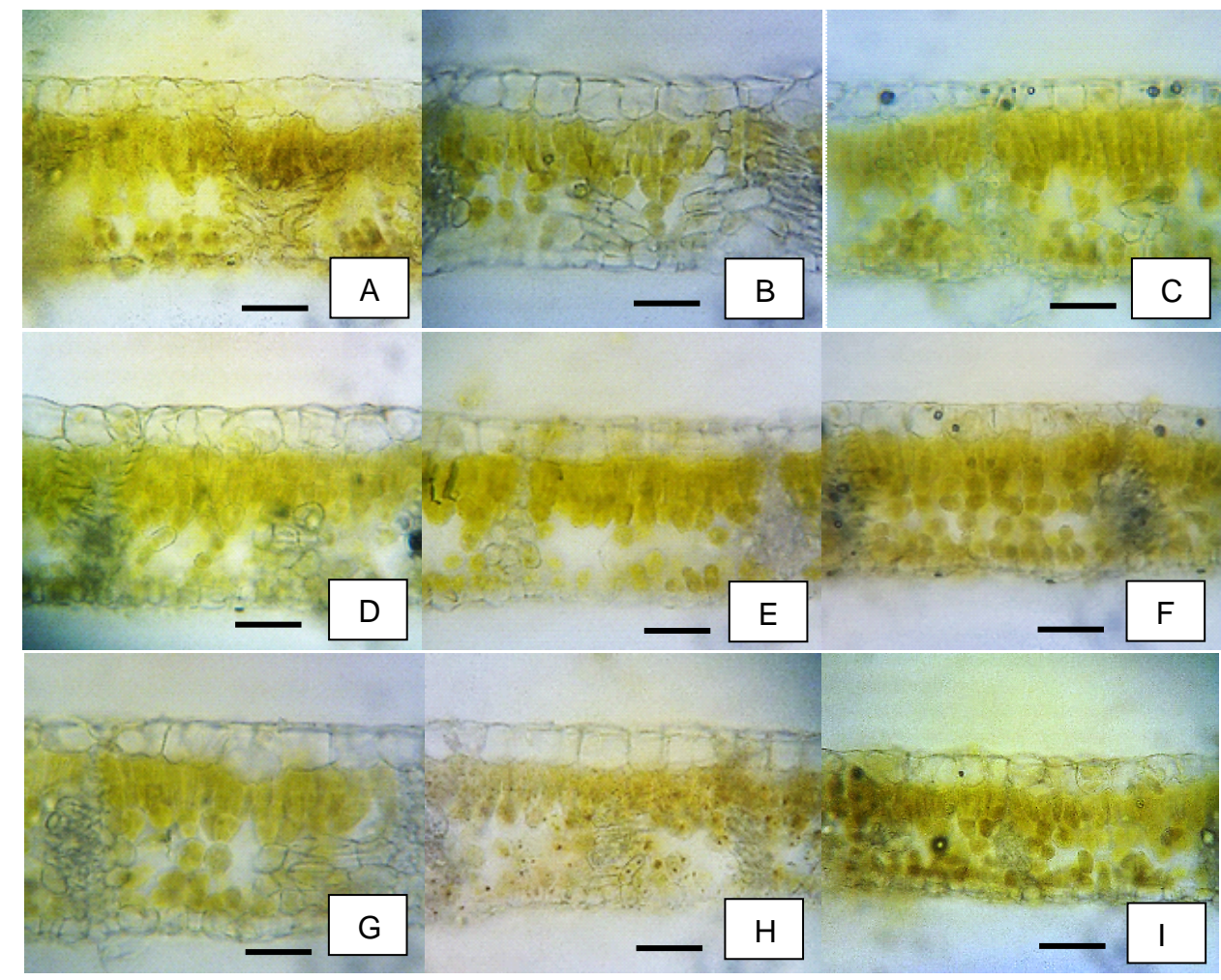

Figure 1. Performance of grafted seedling leaf cells with some cocoa upper stem clones on the watering interval treatment. (A) Sulawesi 1 clone watering every 2 days; (B) KW 641 clone watering every 2 days; (C) ICS 60 clone watering every 2 days; (D) Sulawesi 1 clone watering every 5 days; (E) KW 641 clone watering every 5 days; (F) ICS 60 clone watering every 5 days; (G) Sulawesi 1 clone watering every 8 days; (H) KW641 clone watering every 8 days; (I) ICS 60 clone watering every 8 days. Abbreviation: Upper epidermal (EpA); Mesophyll cell (Mes); Lower epidermal (EpB). 


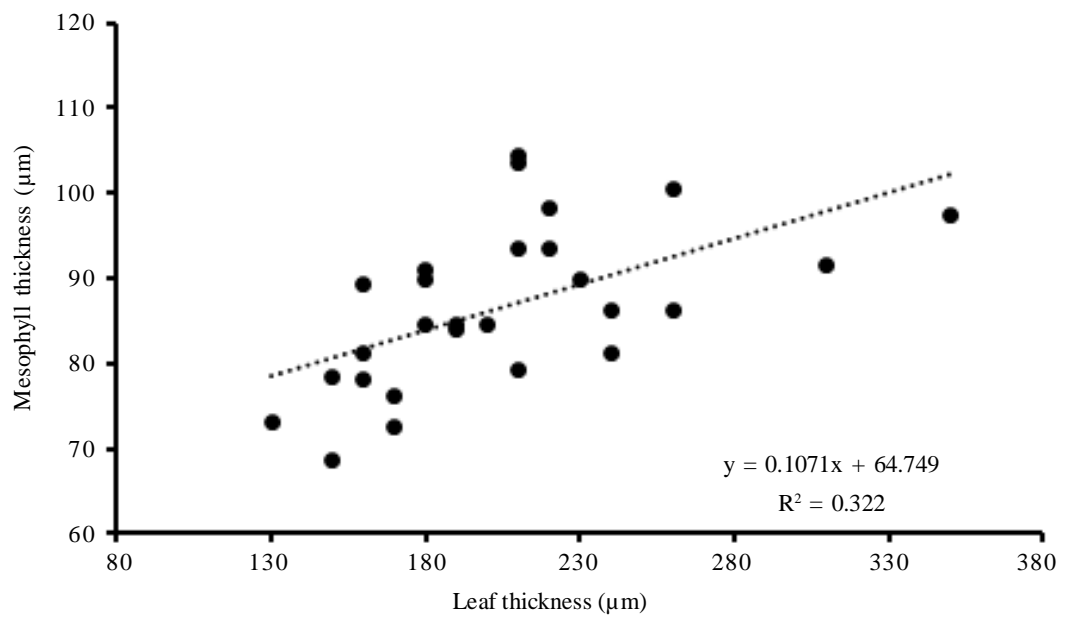

Figure 2. Relationship between mesophyll thickness and leaf thickness

Zakariyya et al. (2016) showed that the leaf thickness could be used as one of the criteria of dry resistant cocoa clone characteristic. Leaf thickness is also reported by Marechaux et al. (2015) as a reflection of cell turgidity specifically on leaves. Furthermore, Afzal (2017) stated that leaf thickness could be used as an indicator of water status in leaves. It is determined by the anatomy including the number, size, and structure of cells in the leaf, which are the leaf parenchyma, mesophyll, and epidermis. The leaf thickness showed the presence of water and solute within the leaf thus causing the leaves to remain turgor in a suboptimum environment. Rhizopoulou \& Psaras (2003) stated that the type of dry plants will adapt by having a thick mesophyll to store more water in the tissue. Ouyang et al. (2017) argue that a thick mesophyll is linear to the number of chloroplasts and gas exchange in the mesophyll, or in other words, the photosynthesis process can be more effective and optimal.

The higher the level of stress, the thinner the mesophyll would be. This fact was in line with research conducted by Zanneti et al. (2016) in which a thinner mesophyll was caused by the parenchyma palisade and sponge tissues that were smaller and thinner.
The thinner mesophyll is a plant's mechanism of tolerance to adjust to the condition of limited water in the environment (Galmes et al., 2013). Epidermal tissues were stated by Wu et al. (2015) to be useful as a detail of plant characteristic that indicates resistance toward dryness. Maiti et al. (2012) added that epidermis can prevent water loss because this tissue is covered in cuticles that contain wax layers. Zhang et al. (2015) used the anatomical characteristics of the epidermis as a criterion of plant resistance characteristic toward dryness. Zanneti et al. (2016) and Lahive et al. (2018) examined that the cocoa seedlings in the condition of water-deficit medium would tend to experience a thickening of the abaxial epidermis. The condition above was an adjustment method for plants to minimize water loss by increasing the resistance of the epidermal tissues. Sari \& Putra (2019) explained one of the responses shown by leaves was the shrinking of tissue size as a consequence of cells quantity decrease, which is produced by the leaf meristem tissues.

The characteristic of stomata is also one of the morphological determinant keys of the cocoa plant resistance against drought. The mechanism of stomatal opening and closure depend on the genetic and environ- 
mental factors (Zakariyya et al., 2017). This process is related to the attempts to conserve water in the body and environment where the plants grow through the transpiration adjustment. The resistant plants would lower the transpiration by narrowing down the stomatal opening.

Table 2 informed that the stomatal density of the cocoa seedlings was influenced by single factors, respectively cocoa clone and watering interval treatment. The seedlings with an upper stem of ICS 60 clone have the highest stomatal density compared to Sulawesi 1 and KW 641 clones both at the beginning and the end of the treatment. The value of stomatal density seems to be increased significantly during the change of interval of watering treatment from every 2 days to 8 days while the change of watering interval from 2 to 5 days does not show a significant change. This is similar to research by Zanneti et al. (2016) and Lahive et al. (2018) that proved the stomatal density to be increased in line with the occurrence of drought threat. Carr \& Lockwoods (2011) explained the increase of stomatal density as compensation of leaf width and stomatal opening that is shrinking.

Table 2. Stomatal density of cocoa clones at multiple levels of drought stress

\begin{tabular}{lc}
\hline Watering interval (days) & Stomata density $\left(\mathrm{mm}^{2}\right)^{-1}$ \\
\hline 2 (normal) & $778.60 \mathrm{a}$ \\
5 (moderate stress) & $846.22 \mathrm{ab}$ \\
8 (severe stress) & $903.62 \mathrm{~b}$ \\
Clones & $914.29 \mathrm{~m}$ \\
ICS 60 & $796.39 \mathrm{n}$ \\
KW 641 & $817.76 \mathrm{n}$ \\
Sulawesi 1 & Nhe numbers followed by the same letter on the \\
\hline Notes: $\quad$ collum and/or row shows the insignificant difference \\
\multicolumn{2}{l}{ according to Tukey 5\%. }
\end{tabular}

Table 3 informed the interaction between watering interval and upper stem clones toward the stomatal opening width at every period of observation. The change in the stomatal opening width in every clone happened as the watering interval increases.
The watering every 8 days significantly influenced the stomatal opening width only on clones with the watering interval of 2 days. On the watering every 8 days, the KW 641 and Sulawesi 1 clones show a narrower stomatal opening compared to the ICS 60 . This indicated that the stomatal opening width that is shrinking is more elastic toward the environmental change, specifically during drought threat. The narrower stomata can cause the water status within the leaf is kept better, proven by the low value of relative water. Winaryo et al. (1997) reported that the GC 7 clone is resistant to drought while the ICS 60 is prone to it based on the osmotic pressure and stomatal characteristics.

The type of plant resistant to drought has a conservative characteristic on water inside the plant, in other words, it can store water by preventing it from excessively lose out through transpiration. When the roots are in the medium of limited water, it then sends a chemical signal in a form of abscisic acid. Abscisic acid is transported from the xylem to leaf. On the other side, the leaf also synthesizes abscisic acid. The condition causes the protein of $\mathrm{K}_{\text {out }}$ channel in the active protective cells and secretes $\mathrm{K}^{+}$in the protective cell, therefore, the potentials of osmotic cells lower and the stomata close (Daszkowska-Golec \& Szarejko, 2013). For the resistant clones, the stomatal characteristics are more responsive to stomatal closure and the few numbers of stomata. This characteristic change is aimed to minimize water loss due to transpiration, thus, the resistant clones are relatively fewer.

Table 3. Stomatal opening width $(\mu \mathrm{m})$ of cocoa clones at multiple levels of drought stress

\begin{tabular}{llll}
\hline \multirow{2}{*}{ Clone } & \multicolumn{3}{c}{ Watering interval } \\
\cline { 2 - 4 } & 2 days & 5 days & 8 days \\
\hline ICS 60 & $2.29 \mathrm{a}$ & $2.02 \mathrm{ab}$ & $1.92 \mathrm{bc}$ \\
KW 641 & $2.14 \mathrm{ab}$ & $1.67 \mathrm{bcd}$ & $1.40 \mathrm{de}$ \\
Sulawesi 1 & $2.12 \mathrm{ab}$ & $1.56 \mathrm{cde}$ & $1.26 \mathrm{e}$ \\
\hline
\end{tabular}

Notes: The numbers followed by the same letter on the collum and/or row shows the insignificant difference according to Tukey 5\%; The mark (-) indicates the absence of interaction among factors. 
The leaf relative water content is a changer that is generally used as a predictor of plant water status, especially during exposure of water threat. The relative water content is influenced by interaction to watering interval and clone treatment. On the ICS 60 clone, the significant decrease in relative water content occurred from the watering interval of 5 days and decreased more on 8 days (Table 4). On the KW 641 and Sulawesi 1 clones, the significant decrease of relative water content occurred on the watering interval of 8 days. The lowest relative water content is shown on the ICS 60 while encountering extreme drought threat, which is $60.83 \%$.

Figure 3 showed the positive linear relationship between mesophyll thickness and relative water content. This indicated that the water status within the leaf is determined by the thickness of mesophyll tissue within the leaf. The leaf anatomy would changes to adjust to the water deficit condition. The lack of water causes cell growth to be hampered, therefore, the leaf thickening is also hampered. Leaves also became thinner due to thinning mesophyll cells (Tomas et al., 2013). The thinning leaf thickness is one of the plant's attempts to adjust to the space inside the leaf on the condition of limited leaf water, therefore, the leaf remains on a turgid condition. The leaf thickness is positively related to the bigger water storage or high content of relative water. The water is in the mesophyll tissue and fills the spaces in cells, therefore, generally, the type of resistant plants will have thicker leaves, which act as relatively bigger water storage under when drought threat occurs.

Table 4. Relative water content (\%) of cocoa clones at multiple levels of drought stress

\begin{tabular}{llll}
\hline \multirow{2}{*}{ Clone } & \multicolumn{3}{c}{ Watering interval } \\
\cline { 2 - 4 } & 2 days & 5 days & 8 days \\
\hline ICS 60 & $86.63 \mathrm{a}$ & $72.90 \mathrm{~cd}$ & $60.83 \mathrm{~d}$ \\
KW 641 & $86.66 \mathrm{a}$ & $81.22 \mathrm{ab}$ & $74.18 \mathrm{~b}$ \\
Sulawesi 1 & $86.31 \mathrm{a}$ & $79.45 \mathrm{ab}$ & $76.42 \mathrm{~b}$ \\
\hline
\end{tabular}

Note: The numbers followed by the same letter on the collum and/or row shows the insignificant difference according to Tukey $5 \%$.

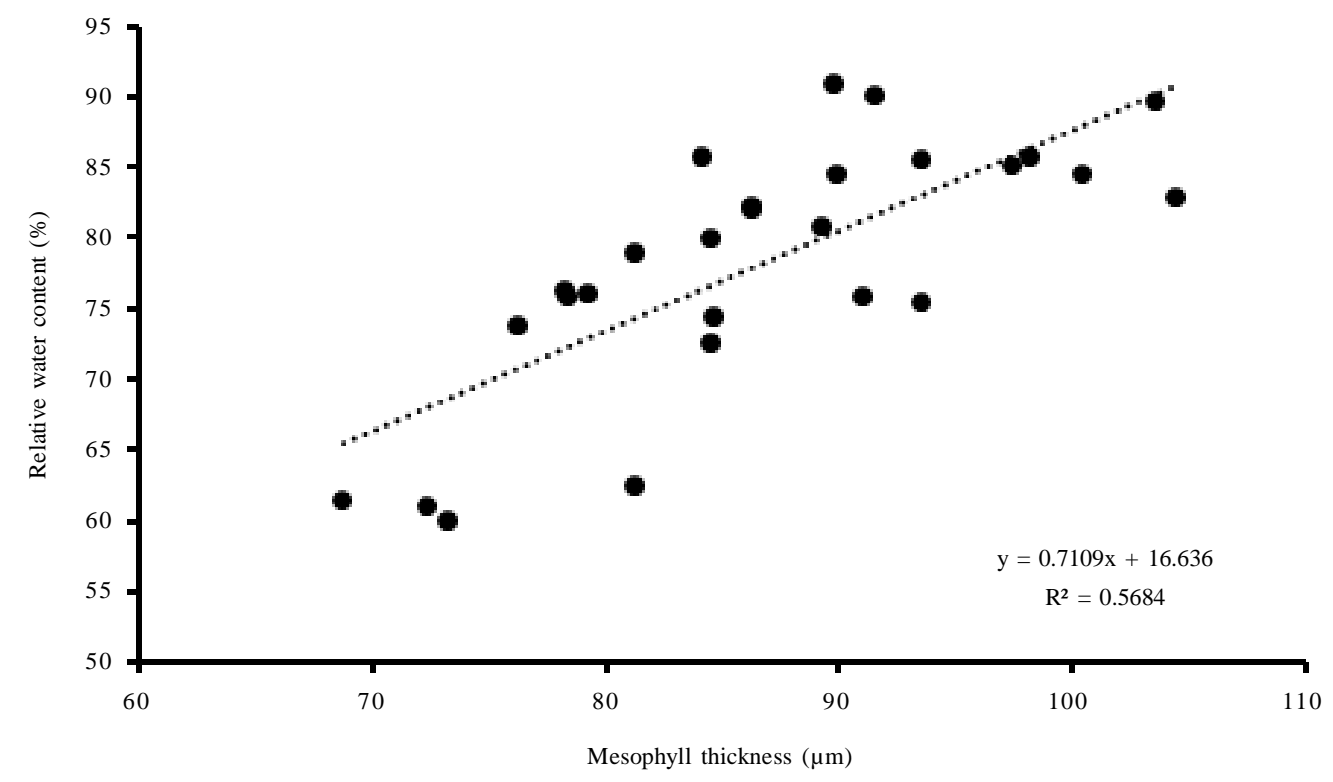

Figure 3. Relationship between mesophyll thickness and relative water content of leaf 


\section{CONCLUSIONS}

Sulawesi 1 and KW 641 cocoa clones had a thicker mesophyll tissue, thicker abaxial and adaxial epidermis, lower stomatal density, narrower stomatal opening, and higher content of relative water compared to the ICS 60 clone. Based on the leaf anatomical characteristics, ICS 60 had a lower resistance against drought stress compared to KW 641 and Sulawesi 1 clones. The watering interval of 8 days (severe drought stress) could cause a decrease in the thickness of mesophyll tissue and abaxial epidermis, increase in stomatal density, stomatal closure, and decrease in the water status within the cocoa plant tissue on all clones. There was a positive linear relationship between the leaf thickness and mesophyll cells. The thicker the leaf mesophyll tissue, the higher the leaf water content is. This informed that the water status within a plant's leaf tissue is determined by the leaf mesophyll thickness.

\section{ACKNOWLEDGEMENT}

The author thanks the Educational Fund Management Institution (LPDP) of the Republic of Indonesia who has funded this research. The author also thanks Mr. Herwanto, Gito Nugraha, and Rizky who have assisted the seedlings preparation.

\section{REFFERENCES}

Agurla, S.; S. Gahir; S. Munemasa; Y. Murrata \& A.S. Raghavendra (2018). Mechanism of stomatal closure in plants exposed to drought and cold stress: Adaptation mechanisms and their applications. Advances in Experimental Medicine and Biology, 1081, 215-232.

Afzal, A.; S. W. Duiker; J. E. Watson (2017). Leaf thickness to predict plant water status. Biosystems Engineering, 156, 148-156.

Binks, O.; P. Meir; L. Rowland; A.C.L. da Costa; S.S. Vasconcelos; A.A.R. de Oliveira;
L. Ferreira; B. Christoffersen, A. Nardini $\&$ M. Mencuccini (2016). Plasticity in leaf level water relations of tropical rainforest trees in response to experimental drought. New Phytologist, 211, 477-488.

Carr, M.K.V. \& G. Lockwoods (2011). The water relations and irrigation requirements of cocoa (Theobroma cacao L.): A Review. Explanation Agriculture, 47, 653-676.

Daszkowska-Golec, A. \& I. Szarejko (2013). Open or close the gate - stomata action under the control of phytohormones in drought stress conditions. Frontiers in plant science, 4, 138.

Galmés, J.; J.M. Ochogavía; J. Gago; E.J. Roldán; J. Cifre \& M.A. Conesa (2013). Leaf responses to drought stress in Mediterranean accessions of Solanum lycopersicum: anatomical adaptations in relation to gas exchange parameters. Plant, Cell, and Environment, 36, 920-935.

Gomez, K.A. \& A.A. Gomez (1995). Prosedur Statistik untuk Penelitian Pertanian. Edisi Kedua. (Terjemahan : Endang Sjamsuddin dan Yustika S. Baharsjah). Universitas Indonesia Press, Jakarta.

Haffani, S.; M. Mezni; M.B. Nasri \& W. Caibi (2017). Comparative leaf water relations and anatomical responses of three vetch species (Vicia narbonensis L., $V$. sativa $\mathrm{L}$. and $V$. villosa Roth.) to cope with water stress. Crop and Pasture Science, 68, 691.

Khosroshahi, M.Z.M.; Esna-Ashari; A. Ershad \& A. Imani (2014). Morphological changes in response to drought stress in cultivated and wild almond species. International Journal of Horticultural Science and Technology, 1, 79-92.

Lahive, F.; P. Hadley \& A. Daymond (2018). The impact of elevated $\mathrm{CO}_{2}$ and water deficit stress on growth and photosynthesis of juvenile cacao (Theobroma cacao L.). Photosynthetica, 56, 911-920.

Maiti, R.; P. Satya; D. Rajkumar \& A. Ramaswamy (2012). Anatomical adaptation for drought and waterlogging stress tolerance. In: 
Crop Plant Anatomy. R. Maiti; P. Satya; D. Rajkumar \& A. Ramaswamy (Eds.). CABI, India.

Maréchaux, I.; M. K. Bartlett; L. Sack; C. Baraloto; J. Engel; E. Joetzjer \& J. Chave (2015). Drought tolerance as predicted by leaf water potential at turgor loss point varies strongly across species within an Amazonian forest. Functional Ecology, 29, 1268-1277.

Mardiyah, S. (2014). Pengaruh Kekeringan dan Pupuk Organik Terhadap Anatomi dan Pertumbuhan Tanaman Padi Gogo (Oriza sativa L. 'Situ Bagendit') pada Tanah Berkapur. Tesis. Universitas Gadjah Mada. Yogyakarta.

Mathobo, R.; D. Marais \& J.M. Steyn (2016). The effect of drought stress on yield, leaf gaseous exchange and chlorophyll fluorescence of dry beans (Phaseolus vulgaris L.). Agricultural Water Management, 180, 118-125.

North, G.B.; E.K. Brinton; M.G. Browne; M.G. Gilman; A.B. Roddy; T.L. Kho; E. Wang; V.A. Fung \& C.R. Brodersen (2019). Hydraulic conductance, resistance, and resilience: how leaves of a tropical epiphyte respond to drought. American Journal of Botany, 106, 1-15.

Ouyang, W.; P.C. Struik; X. Yin \& J. Yang (2017). Stomatal conductance, mesophyll conductance, and transpiration efficiency in relation to leaf anatomy in rice and wheat genotypes under drought. Journal of Experimental Botany, 68, 5191-5205.

Prawoto, A. (1991). Stomata dan palisade kakao kaitannya dengan vigor kultivar. Pelita Perkebunan, 7, 7-14.

Rhizopoulou, S. \& G.K. Psaras (2003). Development and structure of drought-tolerant leaves of the mediterranean shrub Capparis spinosa L., Annalysis Botany, 92, 377-383.

Sari, N.Y. \& F.T.S. Putra (2019). Contribution of calcium to changes leaft anatomy character of oil palm sedlings (Elais quineensis Jacq) under drought stress. Ilmu Pertanian (Agricultural Science), 4, 23-32.
Sass, J.E. (1951). Botanical Microtechnique. $2^{\text {nd }}$ Ed. Iowa (US) : Iowa State College Pr.

Santoso, T.I.; M. Miftahudin; Y.C. Sulistyaningsih \& S. Wiyono (2017). Analysis of secondary metabolites as potential phytoalexins, their secretion sites and proposed resistance markers to vascular streak Dieback in Theobroma cacao L. Pelita Perkebunan, 33, 10-23.

Tomás, M.; J. Flexas; L. Copolovici; J. Galmés; L. Hallik; H. Medrano; M. Ribas-Carbó; T. Tosens; V. Vislap \& Ü. Niinemets (2013). Importance of leaf anatomy in determining mesophyll diffusion conductance to $\mathrm{CO}_{2}$ across species: quantitative limitations and scaling up by models. Journal of Experimental Botany, 64, 2269-2281.

Winaryo; A. Iswanto \& H. Winarno (1997). Kajian penggunaan tegangan osmotik dan kerapatan stomata sebagai kriteria seleksi klon kakao tahan cekaman air. Pelita Perkebunan, 13, 63-70.

Wu, L.J.; Z.H. Li; M.H. Yang \& P.L. Wang (2015). Response of leaf anatomical characteristics of Cyclobalanopsis gilva seedlings to drought stress. Journal of Applied Ecology, 26, 3619-3626.

Zanneti, L.V.; C.R.D. Milanez; V.N. Gama; M.A.G. Aguilar; C.A.S. Souza; E. Campostrini; T.M. Ferraz \& F.A.M.M.A. Figueiredo (2016). Leaf application of silicon in young cacao plants subjected to water deficit. Pesquito Agropecuaris Brasilica, 51, 215-223.

Zakariyya, F.; B. Setiyawan \& A.W. Susilo (2016). Stomatal, proline, and leaf water status characters of some cocoa clones (Theobroma cacao L.) on prolonged dry season. Pelita Perkebunan, 33, 109-117.

Zhang S.B.; Y. Dai; G.Y. Hao; J.W. Li; X.W. Fu \& J.L. Zhang (2015). Differentiation of water-related traits in terrestrial and epiphytic Cymbidium species. Frontier Plant Science, 6, 260.

$$
* * 0 * *
$$

